\title{
Information and Commentary
}

\section{Establishing biomedical waste management system in Medical University of India - A successful practical approach}

\author{
Reema Kumari $^{a, *}$, Kirti Srivastava ${ }^{b}$, Anupam Wakhlu ${ }^{c}$, Anshita Singh ${ }^{d}$ \\ ${ }^{a}$ Associate Professor, Department of Community Medicine \& Public Health, King George Medical University, \\ Lucknow, Uttar Pradesh, India \\ ${ }^{\mathrm{b}}$ Associate Professor, Department of Radiotherapy, King George Medical University, Lucknow, Uttar Pradesh, India \\ c Assistant Professor, Department of Rheumatology, King George Medical University, Lucknow, Uttar Pradesh, India \\ ${ }^{\mathrm{d}}$ Ph.D Scholar, King George Medical University, Lucknow, Uttar Pradesh, India
}

\section{A R T I C L E I N F O}

Article history:

Received 18 September 2012

Accepted 29 November 2012

Available online 8 December 2012

Keywords

Biomedical waste

Segregation

Recycle

Reuse

Health hazards

\begin{abstract}
A B S T R A C T
Biomedical waste management (BMWM) has become an important issue as it poses potential health risks and damage to the environment. Biomedical waste (BMW) if not handled in a proper way, is a potent source of diseases like HIV, Hepatitis B \& C and other bacterial diseases causing serious threat to human health so prime attention needed for its safe and proper disposal. Bio-medical waste includes all the wastes generated from hospitals, medical centres, healthcare establishment and research facilities in diagnosis, treatment, immunization and associated research. According to CAG (Civic Action Group) report Government of India, 2009 there was poor management, poor awareness and lack of commitment from the top management regarding waste management practices in healthcare establishments. This paper looks upon the aspects and step-by-step approach for establishing BMWM System in tertiary level hospital and planning to make this centre a model to provide hands on training to all State Medical Colleges and other hospitals to help them establish BMWM System.
\end{abstract}

Copyright @ 2012, INDIACLEN. Publishing Services by Reed Elsevier India Pvt Ltd. All rights reserved.

\section{Introduction}

Biomedical waste generated from various health care institutions has created tremendous environmental and public health problems. The all-cause mortality data from India and other developing countries show that infectious disease is the most common cause of death. ${ }^{1}$ Improper BMW Management has the potential to spread infections, lead to development of resistant organisms and bringing these resistant hospital organisms to the doorstep of the community. Further, biomedical waste has the potential for polluting air, water, food and is foul smelling and ugly to look at. In 2002, the

\footnotetext{
* Corresponding author. Tel.: +91 (0) 9793604236.

E-mail address: reema_tua05@yahoo.co.in (R. Kumari). 2213-3984/\$ - see front matter Copyright @ 2012, INDIACLEN. Publishing Services by Reed Elsevier India Pvt Ltd. All rights reserved. http://dx.doi.org/10.1016/j.cegh.2012.11.004
} 
results of a WHO assessment conducted in 22 developing countries showed that the proportion of healthcare facilities that do not use proper waste disposal methods range from $18 \%$ to $64 \% .^{2}$

The Ministry of Environment and Forests Govt. of India notified the "Biomedical Waste (Management and Handling) Rules" in July $1998 .^{3}$ In accordance with these rules, it is mandatory for the producer of biomedical waste to ensure its safe disposal. Despite a formal law, BMWM has not been given adequate emphasis by healthcare facilities in India and other developing nations. UNDP (United Nations Development Programme) Govt. of India sponsored a project for establishing BMWM System in this tertiary level hospital. It can be a role model for those who really want to improve their hospital image. Learning and BMWM implementation strategies can encourage other hospitals to develop a smooth running BMWM System in a tertiary level healthcare centre.

\section{Need of BMWM System for hospitals}

A number of studies have indicated that the inappropriate handling and disposal of healthcare waste poses health risks to health workers who may be directly exposed and to people near health facilities, particularly children and scavengers who may become exposed to infectious wastes and a higher risk of diseases like hepatitis and HIV/AIDS, ${ }^{4-8}$ and $\left.{ }^{9}\right]$. The World Health Organization estimates that each year there are about 8-16 million new cases of Hepatitis B virus (HBV), 2.3 to 4.7 million cases of Hepatitis $C$ virus (HCV) and 80,000 to 160,000 cases of human immune deficiency virus (HIV) due to unsafe injections and mostly due to very poor waste management systems. ${ }^{9,10}$ In less developed and transitional countries, waste disposal options are limited, and small-scale incinerators have been used as an interim solution. Incinerators emit a variety of harmful pollutants, including particulate matter, mercury, dioxin and furans ${ }^{11}$ that pollute the environment.

\section{Background status}

King George Medical University, Lucknow, U.P, India is a premier 100 years old, 3000 bedded tertiary care institution, which had no credible biomedical waste management plan or facility till about 2 years ago. Since the establishment of the institute, BMWM was not given due importance and was highly neglected. No segregation of the waste was done. Knowledge regarding BMWM amongst the employees was almost nil. No dedicated equipments or site for disposal of waste was available. ${ }^{12}$ The issue gained some momentum when a project on injection safety was launched in the year 2007 by IndiaCLEN Program Evaluation Network (iPEN). BMWM was a part of this project and a regular training regarding safe injection practices along with knowledge for BMWM was given. Some initiative was then taken by the administration and a waste management committee was formed in the year 2009.

\section{Strategy to establish BMWM system}

The most important step for implementation of BMWM in a healthcare facility would be motivation and awareness of the administration. It is a sound organizational policy to have a waste management committee, especially in a large hospital and therefore a Waste Management Committee (WMC) was formed in the year 2009 with the following objectives.

a. To evolve and formulate the hospital waste management policy and ratify it.

b. To lay down the duties of various officers/workers for hospital waste management

c. To evaluate and monitor effective waste management in hospital

d. To formulate training programs for all healthcare employees

\subsection{A step-by-step approach}

\subsubsection{Step-1: Administrative frame worker}

4.1.1.1. Formation of Waste Management Committee (WMC)

- WMC consist of Head of the Institution, Chief Medical superintendent, Financial Officer (FO), Registrar, Matron, Civil Engineer, Sanitary Inspectors, Head of some clinical departments and member secretary. It was made mandatory for the WMC to have quarterly meetings and discuss about the progress made so far and to formulate further action plans.

\subsubsection{Member secretary}

- Member secretary of Waste Management Committee is the key person responsible for all the activities related to BMWM as Formulation of the policies, procure infrastructure and made it available at each and every work station in the hospital, Formulating training and monitoring modules and work in coordination with the higher authorities.

\subsubsection{Nodal officer (NO)}

- A faculty member from every department was appointed as Nodal officer for BMWM. The NO is made responsible for each and every activity related to BMWM in their department. The NO has to implement the BMWM practices as per the norms and hospital policy in the department.

- NO can also formulate a subcommittee consisting of the staff nurses, ward boys, resident doctors etc who are directly related to the day to day activities in generation of BMW. The members of the subcommittee were supposed to report to the Nodal officer in case of any requirement, complaints, non-compliance, solutions regarding disposal of any specific category of waste generated in the department. NO are instructed to co-ordinate with the member secretary and also to participate in various Monitoring and Training activities being conducted in the hospital. 
4.1.2. Step-2: Baseline assessment of waste produced in the HealthCare Facility

This assessment was done for determining the percentage of different category of waste produced in the HCF. Baseline assessment gives strength to BMWM System. During baseline assessment waste was not segregated properly. All the hospital waste was collected at the temporary area.

(Area identified \& allocated for waste collection \& treatment process). Result: Quantity of waste generated in the hospital - 2484/kg, mixed waste untidy.

\subsubsection{Importance of performing baseline assessment}

This assessment provided the exact quantity of various categories of waste generated in the hospital and thereby giving us data for procuring various equipments for terminal disposal and for the Common Treatment Facility (CTF). It helps in assessing the current situation \& provides systemic approach \& methodology to improve the BMWM System.

\subsubsection{Step-3: Planning and implementation}

A BMWM Cell has been established at KGMU which is the point of coordination of various activities being undertaken for improving the waste management situation in the Institute. The BMWM Cell furnished with all required necessary facilities. The BMWM Cell also manages the records pertaining to the various waste management procedures and policies adopted in the hospital. Specialized infrastructure has also been developed under the project.

- Infrastructure for waste segregation: Colour coded bins and posters guiding the colour coding scheme.

- Waste collection and transportation: Trolleys have been specially designed and fabricated for collection of waste. Waste collection trolleys have been procured for transportation of waste within the wards. For transportation of waste from department to the Central Collection and Treatment Site (CCTS), rickshaw trolleys have been procured.

Seven routes have been designed for collection and transportation of waste from all the departments of KGMU. The timings and frequency of waste collection from wards have been adopted in consultation with the respective nursing staff so as to assure minimum intervention while the ward staffs are performing their duties.

\subsubsection{Step 4: Allocation of Funds}

Funds are needed for activities illustrate in Table 1

\subsubsection{Step-5: Preparation of Central Collection and Treatment Site (CCTS)}

4.1.6.1. Central Collection and Treatment Site (CCTS). A site situated in a comparatively secluded area in the hospital surrounded by greenery was selected. Site is designed in the manner so that different category of collected waste can be stored and finally treated and disposed off as per the norms. The facility is large enough to house the machines used for storage and disposal of recyclable waste. The size and number of the machines are decided according to the requirement and size of the facility. For incinerable waste, it is better to tie up with some authorized CTF because if the facility achieves good segregation then the incinerable waste produced would be less than $10 \%$ of the total waste and in that case it will never be cost effective to install incinerator at the facility. Records are maintained regarding quantity of different categories of waste, needle prick injuries occurs at different work station, autoclave cycles, autoclave testing with biological indicators, weight of waste at every step of treatment, training

\section{Table 1 - Funds are needed for performing activities related to biomedical waste management.}

\begin{tabular}{|c|c|}
\hline 1. Consumables & $\begin{array}{l}\text { - Hub cutters, bins, poly bags of different colours, protective } \\
\text { gear (gown, mask, protective boots, eye protector, gloves etc) }\end{array}$ \\
\hline & - IEC materials/training \\
\hline 2. Equipment & - Autoclave [two autoclave \\
\hline & (375 lit. of capacity) used in our hospital] \\
\hline & - Shredder [two shredder machines $(50-100 \mathrm{~kg} / \mathrm{hr}$. of capacity) used in our Hospital] \\
\hline & - Trolleys and other containers: \\
\hline & a) Collection and transportation trolleys: \\
\hline & 1. Work station trolley (for wards having bins) \\
\hline & 2. Injection trolley (for wards having bins) \\
\hline & 3. Rickshaw trolley (Department to CCTS) \\
\hline & 4. Wheel trolley (ward waste collection) \\
\hline & b) For loading and deloading of waste at Site (CCTS): \\
\hline 3. Manpower & Required for following activities: \\
\hline & 1. Collection of waste from various work stations \\
\hline & 2. Operating machines \\
\hline & 3. Data entry/record keeping \\
\hline & $\begin{array}{l}\text { 4. Distributing consumables, hub cutter repair, attending to the } \\
\text { complaints from various departments. }\end{array}$ \\
\hline & 5. Organizing regular training sessions and monitoring rounds \\
\hline 4. Infrastructure & Site development and its maintenance \\
\hline 5. Incineration cost & To have contract with an authorized CTF \\
\hline
\end{tabular}




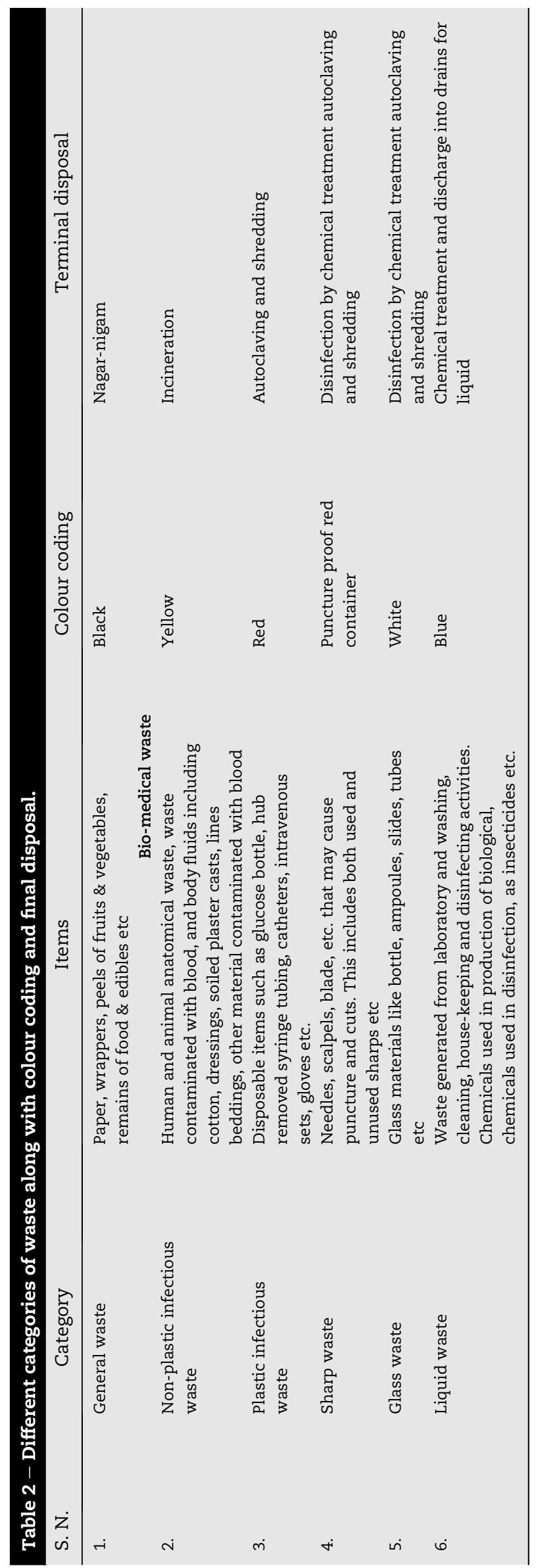

programme and monitoring rounds. For the purpose of waste tracking and to avoid pilferage, waste tracking is setup. Under this system booklet are being provided to all the departments. This has to be verified and countersigned by the Nodal officer of the respective department and report sent every month to the BMWM Cell. Currently, site specific labelling is being carried out for bags. A bar-coded tracking system for waste management is under development.

4.1.7. Step-6: Colour coding system and segregation of waste: Table 2

4.1.7.1. Segregation. Segregation of waste is done in every department at each work station-wards, Operation theatres, immunization room, OPD's etc (Fig. 1). Placement of different colour coded bins should be done according to requirement.

- Development of IEC materials:

- Pamphlets, bed side stickers, hoardings

Slogan in OPD ticket, announcements in the OPD complex Charts displaying colour coding and other information to be mounted in the BMWM Cell where regular training sessions should be conducted.

- PPP - movies, skit, games

\subsubsection{Step-7: Transportation of waste}

Transportation of waste is done by different trolleys. Work station trolleys and small trolleys are placed inside wards, wheel trolleys are placed at each department for collection of waste at each department. Segregated waste from each department is transported to CCTS through rickshaw trolleys.

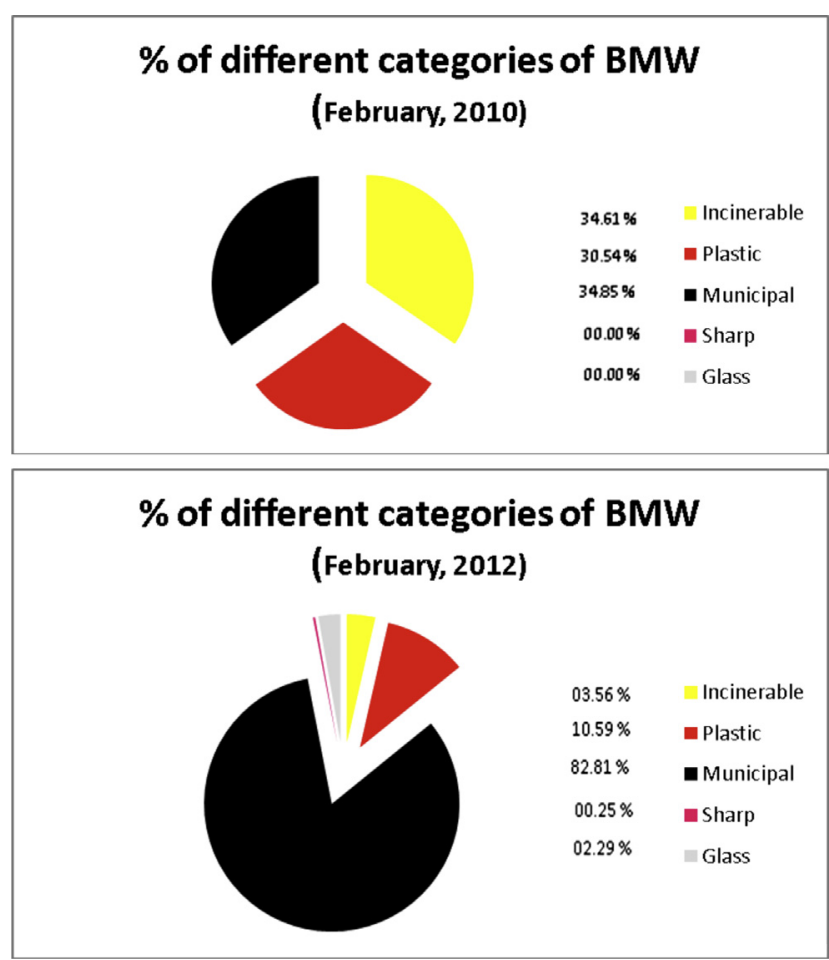

Fig. 1 - Different categories of waste generated, year 2010 \& 2012. 


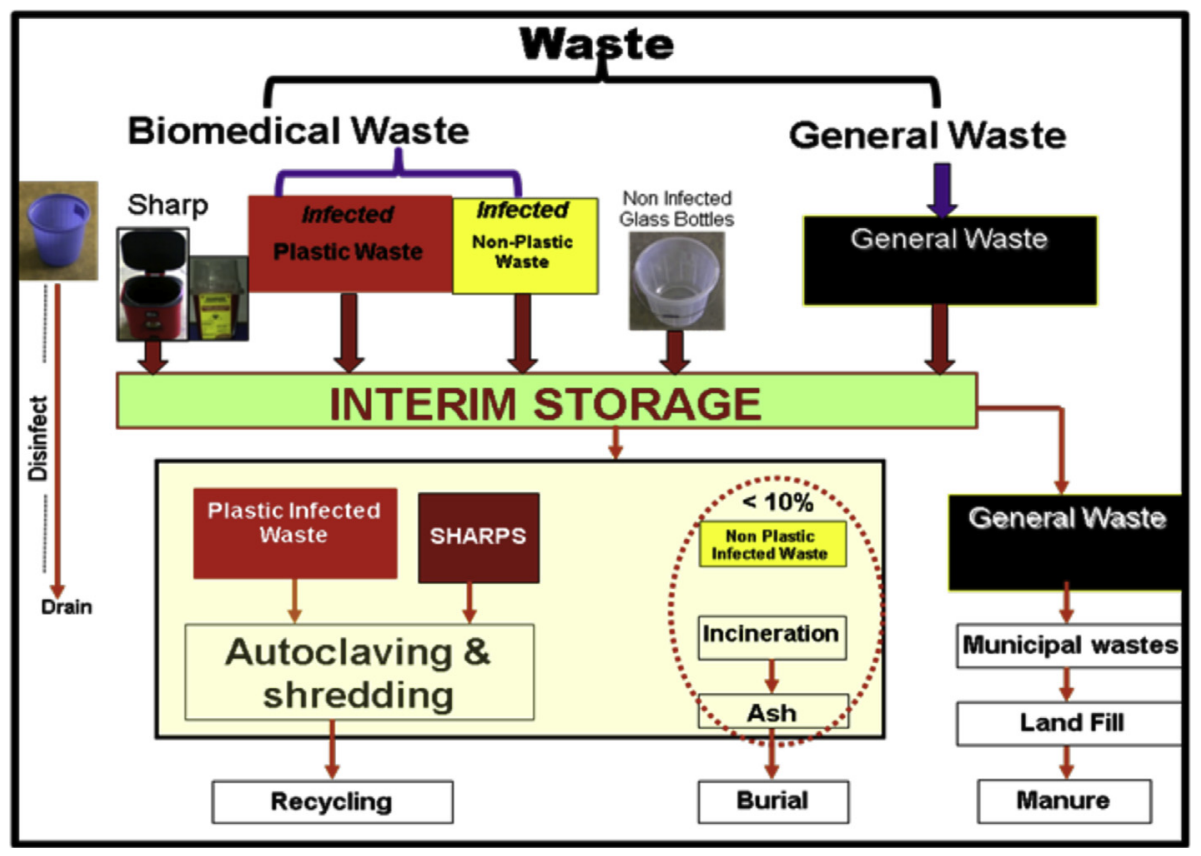

Fig. 2 - Functioning of BMWM System.

4.1.9. Step-8: Terminal disposal at Central Collection and Treatment System (CCTS) site (Fig. 2)

Segregated waste from each department collected at the CCTS site. At the site Autoclave and Shredders are installed for terminal disposal of plastic waste. General waste collected by Nagar-Nigam workers. Highly infectious non-plastic waste send for incineration process (University has tie up with a private company-SYNERGY BMW Management System, appr. $35 \mathrm{~km}$ from the city).

\subsubsection{Step-9: Sustainability of BMWM System}

A smooth running BMWM System require a lot of efforts. Development of BMWM System is the biggest deal but its proper maintenance with time to time is also another significant task. Regular training program and monitoring maintain the BMWM System.

a) Training and awareness raising programmes: Regular and updated training program helps to aware the healthcare personnel. Training programs are conducted in every department as per requirement.

- Central Channel: Chief Medical Superintendant (CMS): Nodal officers, Residents, Interns, Safai karmchari, Sanitary inspectors, PROs, Paramedical staff, Social workers.

- Departmental level: Individual training sessions conducted by the nodal officer of the department as well as at least two nodal officers from other departments.

b) Certificate Course in HealthCare Waste Management (CHCWM): A 6 month certificate course in HealthCare Waste Management through IGNOU for Nodal officers/staff.

c) Monitoring rounds: Regular monitoring by the NO and the members of BMWM Committee helps to improve BMWM System. This record helps to evaluate the departments that require more attention for segregation at the point of generation. During monitoring rounds points observed are-
- Segregation of waste.

- Position of poster and bins.

- Maintenance of bin.

- Record keeping.

- Protective gears are using or not.

- Infrastructure requirement.

- Number of Health Care Personnel (HCP) not attending training program.

- Knowledge of HCP about BMWM System.

- Suggestions of HCP for further improvement of BMWM System

University has got Authorization certificates through Uttar Pradesh Pollution Control Board (UPPCB), India.

\section{Conclusion}

Establishing BMWM System in a tertiary care hospital appears to be a difficult job but with our consistent team hard work it was not impossible to achieve our goal. Motivation right from top to bottom is the key to success. Funds to provide infrastructure is definitely needs but could be partly compensated by the revenue generated out of the plastic waste. Cost involved in incineration process could be minimized by excellent Segregation which reduces to $8-10 \%$ of the total waste. Future Planning is under process to make this centre a model to provide hands on training through IGNOU to all State Medical Colleges and other hospitals to help them establish BMWM System in their hospital.

\section{Conflicts of interest}

All authors have none to declare. 


\section{Acknowledgment}

As part of this collective initiative (GEF-UNDP-MoEF-IGNOU), we are extremely grateful to all International and national experts. The authors wish to express their sincere gratitude to Dr. M. Subba Rao, Director, MoEF, Dr. Megha Rathi, UNDP, Dr. Ashok Agarwal from IGNOU and Dr. Subhangi Wankhede from MoEF for their initiative and effort to develop the BMWM System in the K.G Medical University. We gratefully acknowledge Waste Management Committee and administration of K.G Medical University for their support and valuable suggestions.

\section{R E F E R E N C E S}

1. WHO. World health report. 2002.

2. WHO. Management of Solid Healthcare Waste at Primary Healthcare Centres, A Decision-making Guide. Geneva: World Health Organisation; 2005.

3. Bio-Medical Wastes (Management and Handling) Rules: Gazette by Govt. of India (1998/2000).

4. Adegbita MA, Nwafor SO, Afon A, Abegunde AA, Bamise CT. Assessment of dental waste management in a Nigerian tertiary hospital. Waste Manag Res. 2010;28:769-777.
5. Coker. Medical waste management in Ibadan, Nigeria: Obstacles and Prospects. February 2009. Waste Manag. 2009;29(2):804-811.

6. PATH. Achieving Effective Sharps Waste Management in GAVI Host Countries. A Proposed Approach with Estimates of Cost 2006. Available at: http://www.Path.org/files/TS_ach_eff swm. pdf; 2009. Accessed 27.07.09.

7. Oke IA. Management of immunization solid wastes in Kano state, Nigeria. Waste Manag. 2008;28:2512-2521.

8. WHO. Wastes from Healthcare Activities. Fact Sheet No 231, April 2002. Available at: http://www.who.int/mediacentre/ factsheets/fs231/en/; 2002. Accessed 12.09.09.

9. World Health Organisation. Unsafe injection practices and transmission of blood borne pathogens. Bull World Health Organ. 1999;77:787-819.

10. Townend WK, Cheeseman CR. Guidelines for the evaluation and assessment of the sustainable use of resources and of wastes management at healthcare facilities. Waste Manag Res. 2005;23:398-408.

11. Malkan S, Nelson J. Global trends in responsible healthcare waste management - a perspective from health care without harm. Editorial J Waste Manage. 2005;25: 570-572.

12. Gupta Saurabh, Boojh Ram, Mishra Ajai, Verma Shalini, Agarwal Neeraj. Biomedical waste management practices at Chhatrapati Shahuji Maharaj medical University, Lucknow: a case study. Res Environ Life Sci. 2008;1(2):77-80. 